\title{
PERAN KREATIVITAS GURU DALAM PENGGUNAAN MEDIA BELAJAR DAN MINAT BELAJAR DALAM MENINGKATKAN PRESTASI BELAJAR PESERTA DIDIK SMK DI JAKARTA SELATAN
}

\author{
Fadli Rasam dan Ani Interdiana Candra Sari \\ Dosen Program Studi Pendidikan Ekonomi Universitas Indraprasta PGRI \\ Email: fadrasam@gmail.com
}

\begin{abstract}
Abstrak
Tujuan dari penelitian ini adalah ingin memperoleh jawaban secara empirik pengaruh (1) kreativitas guru dalam penggunaan media belajar dan minat belajar terhadap prestasi belajar peserta didik secara simultan, (2) kreativitas guru dalam penggunaan media belajar terhadap prestasi belajar peserta didik secara partial, (3) minat belajar terhadap prestasi belajar peserta didik secara partial. Penelitian ini dilaksanakan di Sekolah Menengah Kejuruan Jakarta Selatan dengan responden 160 peserta didik. Metode yang digunakan adalah survei dengan pendekatan analisis regresi linear ganda. Berdasarkan penelitian dan perhitungan SPSS diperoleh hasil penelitian sebagai berikut: (1) Terdapat pengaruh kreativitas guru dalam penggunaan media belajar dan minat belajar terhadap prestasi belajar peserta didik secara simultan. (2) Terdapat pengaruh kreativitas guru dalam penggunaan media belajar terhadap prestasi belajar peserta didik secara partial (hal ini menandakan bahwa semakin kreatif dan bervariasi media yang digunakan guru dalam pembelajaran terbukti dapat meningkatkan semangat dan prestasi belajar peserta didik). (3) Terdapat pengaruh minat belajar terhadap prestasi belajar secara partial (hal ini menandakan bahwa semakin baik minat yang dimiliki peserta didik dalam pembelajaran terbukti akan meningkatkan prestasi belajar peserta didik). Kepiawaian guru dalam mengelola media belajar akan membuat peserta didik semangat dan timbul minat dalam diri mereka untuk aktif dalam proses pembelajaran sehingga akan mempengaruhi prestasi belajar peserta didik. Kreativitas guru akan membantu dalam penyampaian materi pelajaran kepada siswa sehingga mereka merasa tertantang, menarik dan tidak jenuh. Kreativitas guru yang baik menyebabkan pembelajaran menyenangkan bagi siswa.
\end{abstract}

Kata Kunci: Kreativitas guru dalam penggunaan media belajar, minat belajar dan prestasi belajar

\section{PENDAHULUAN}

Rendahnya mutu pendidikan dan rendahnya kualitas pendidikan di Indonesia sangatlah memprihatinkan. Menurut laporan Education for all (EFA) Global Monitoring Report yang dirilis oleh UNESCO 2012, perkembangan pendidikan Indonesia berada pada peringkat ke-64 dari 120 negara.

Masalah dalam dunia pendidikan mendapatkan perhatian yang sungguhsungguh dari pemerintah. Pemerintah berupaya untuk meningkatkan mutu pendidikan, melakukan pembangunan dan pembaharuan di bidang pendidikan. Pembangunan tersebut meliputi pembangunan berbagai sarana fisik dan non fisik yang menunjang kelancaran pendidikan dan penyempurnaan dan peraturanperaturan tentang pendidikan yang sesuai dengan undang-undang serta pembaharuan dalam proses belajar mengajar, meningkatkan kualitas tenaga 
pendidikan antara lain guru dan dosen. Guru adalah pendidik profesional dengan tugas utama mendidik, mengajar, membimbing, mengarahkan, melatih, menilai, dan mengevaluasi peserta didik pada pendidikan anak usia dini jalur pendidikan formal, pendidikan dasar, dan pendidikan menengah. (UU. RI. No. 14 Tahun 2005, Bab 1, Pasal 1 tentang Guru dan Dosen)

Berbagai permasalahan muncul di dunia pendidikan karena rendahnya motivasi belajar peserta didik, seperti banyaknya pencapaian hasil belajar peserta didik yang rendah, keinginan mencapai cita-cita dengan instan dan tawuran antar pelajar. Survei tentang kemampuan siswa Indonesia pada artikel online tahun 2013, pada tahun 2007 survei 'Trends in International Math and Science' Global Institute mencatat hanya 5\% siswa Indonesia mampu mengerjakan soal berkategori tinggi yang memerlukan penalaran. Sebanyak $78 \%$ siswa Indonesia justru dapat mengerjakan soal-soal kategori rendah yang hanya memerlukan hafalan, hasil lainnya yaitu catatan Programme for International Student Assessment (PISA) tahun 2009, Indonesia menempati peringkat 10 besar terbawah dari 65 negara peserta PISA. Survei diadakan setiap tiga tahun sekali sejak 2000. PISA menyertakan siswa berusia 15 tahun dari 65 negara, baik negara maju maupun negara berkembang. Kriteria penilaian PISA mencakup kemampuan kognitif, dan keahlian siswa dalam membaca, matematika, dan sains.

Menurut catatan PISA pada tahun 2009, siswa di Indonesia secara umum hanya dapat menguasai pelajaran sampai level 3 saja, sedangkan banyak siswa negara lain yang menguasai pelajaran hingga level 4, 5, bahkan 6. Survei Global Institute 2007 dan hasil PISA 2009 dirangkum dalam satu kesimpulan: prestasi siswa Indonesia rendah dibanding negara lain. Sedangkan perolehan hasil survei PISA tahun 2013 menyatakan bahwa dari total 65 negara dan wilayah yang masuk survei PISA, Indonesia menduduki ranking ke-64. Rendahnya prestasi peserta didik Indonesia tidak hanya karena motivasi belajar, namun juga faktor pengajaran, lingkungan belajar peserta didik dan kemampuan dari peserta didik sendiri.

Prestasi belajar yang baik atau yang memuaskan dipengaruhi banyak hal antara lain kondisi keluarga dan lingkungan, seperti media massa (televisi, playstation, internet dll), kreativitas dan minat belajar siswa. Hasil belajar siswa 
merupakan perubahan tingkah laku yang menyangkut aspek kognitif, afektif, dan psikomotorik (Sudjana, 2005:30).

Salah satu faktor intern yang mempengaruhi prestasi belajar adalah kreativitas guru dalam pemanfataan media belajar. Kreativitas adalah kemampuan mengimajinasikan, menafsirkan dan mengemukakan gagasan serta usaha yang memiliki daya cipta untuk kombinasi baru dari unsur sebelumnya yang sudah ada sehingga diperoleh peningkatan kualitas siswa dalam pengembangan dirinya. (http://journal.unnes.ac.id/sju/index.php/eeaj)

Kreativitas guru merupakan suatu tuntutan yang harus dapat diterima oleh seorang guru untuk meningkatkan kompetensinya di tengah pesatnya perkembangan iptek. Guru yang tidak atau kurang kreatif akan ditinggal oleh siswa. Kreativitas guru akan membantu dalam penyampaian materi pelajaran kepada siswa sehingga mereka merasa tertantang, menarik dan tidak jenuh. Kreativitas guru yang baik menyebabkan pembelajaran menyenangkan bagi siswa. Kemampuan kreativitas guru secara individu berbeda. Seseorang yang kreatif cenderung orisinal/asli daripada seseorang yang kurang kreatif. Seseorang yang kreatif cenderung lebih luwes dan fleksibel karena dapat dan mau beralih dari pendekatan ke pendekatan lain apabila menangani suatu masalah. Serta suka dengan hal-hal yang rumit dan lebih mandiri dan memegang teguh pendiriannya. Kreativitas guru akan terlihat nyata atau berhasil jika siswa berani bertanya, observasi dan mengutarakan pendapatan atau usulan-usulan.

Apabila dalam proses belajar mengajar siswa mempunyai ketertarikan terhadap materi pelajaran dan didukung oleh guru dalam menyampaikan materi dengan cara yang menarik sehingga siswa menjadi tertarik untuk mempelajari materi maka keberhasilan kegiatan pembelajaran akan mudah tercapai. Salah satu cara supaya proses pembelajaran menarik adalah dengan menggunakan media pembelajaran. Media pembelajaran audiovisual (komputer multimedia) sebagai salah satu media yang baru dengan perangkat lunak (Software/Aplikasi) yang dapat di tayangkan melalui media komputer, televisi atau layar lebar. Media pembelajaran audiovisual menjadikan kegiatan pembelajaran semakin menarik, bahkan kegiatan demonstrasi atau peragaan dan praktikum pun dapat dilaksanakan. Media komputer maupun audiovisual lainnya telah banyak digunakan di sekolah-sekolah, kerena alat ini dapat membantu siswa dalam 
menguatkan pemahaman bahan ajarnya. Media pembelajaran mempunyai manfaat dan kegunaan yang sangat baik dan bisa menjadi salah satu faktor pendukung untuk mencapai kualitas pembelajaran yang diharapkan. Salah satu kemampuan guru yang harus dilaksanakan dalam proses pembelajaran adalah kemampuan dalam menggunakan sejumlah media pembelajaran yang tepat dengan konteks materi ajar. Hal ini bilamana dilakukan dengan baik maka dapat meningkatkan motivasi belajar siswa dan minat yang pada akhirnya dapat menentukan prestasi belajar siswa di sekolah.

Menurut Hamalik (2005:15) pemakaian media pembelajaran dalam proses belajar mengajar dapat membangkitkan keinginan dan minat yang baru, membangkitkan motivasi dan rangsangan kegiatan belajar, dan bahkan membawa pengaruh-pengaruh psikologis terhadap siswa. Djamarah dan Suwarna mengungkapkan indikator media pembelajaran power point sebagai berikut: (1) ketepatan media pembelajaran power point dengan tujuan pembelajaran; (2) kesesuaian media pembelajaran powerpoint dengan taraf berfikir siswa; (3) ketersedian waktu untuk menggunakan media pembelajaran; (4) bersifat interaktif dan content rich.

Selain kreativitas yang penting untuk dipedulikan dalam proses belajar mengajar yaitu minat. Minat belajar besar sekali pengaruhnya terhadap prestasi belajar sebab dengan minat seseorang akan melakukan sesuatu yang diminatinya. Sebaliknya tanpa minat seseorang tidak mungkin melakukan sesuatu. Untuk itu guru diperlukan kemampuan untuk menciptakan suasana agar siswa terangsang untuk lebih ingin mengetahui materi, senang menanyakan dan berani mengajukan pendapat, serta melakukan percobaan yang menuntut pengalaman baru. Fenomena yang terjadi dilapangan beberapa guru berpendapat bahwa siswa dalam proses belajar-mengajar tidak bersemangat dalam mengikuti pelajaran, siswa cenderung pasif dalam menerima penjelasan dari guru. Selain itu, dalam mengerjakan tugas pelajaran yang diberikan guru siswa mengerjakan tugas tersebut asal jadi, tidak tepat waktu dalam mengumpulkan bahkan tidak mengerjakan sama sekali. Kenyataan lain menunjukkan guru dalam proses belajar-mengajar hanya memberikan materi pelajaran saja. Guru jarang sekali memberikan motivasi pada siswa dalam mengajar. Hal ini disebabkan banyaknya jumlah pokok bahasan yang 
harus diajarkan sehingga guru cenderung hanya memberikan materi saja tanpa berusaha membangkitkan minat dan motivasi belajar siswa.

Dari masalah yang ditemui diatas, maka peneliti akan melakukan studi komprehensif untuk menganalisis "Peran Kreativitas Guru dalam Penggunaan Media Belajar dan Minat Belajar dalam Meningkatkan Prestasi Belajar Peserta Didik SMK di Jakarta Selatan”.

\section{TINJAUAN PUSTAKA}

\section{Prestasi Belajar}

Pengertian belajar menurut beberapa ahli adalah (a) Whittaker, belajar adalah proses tingkah laku yang ditimbulkan atau diubah melalui latihan atau pengalaman, (b) Kimble, belajar adalah perubahan relatif permanen dalam potensi bertindak, yang berlangsung sebagai akibat adanya latihan yang diperkuat, (c) Winkel, belajar adalah aktivitas mental atau psikis, yang berlangsung dalam interaksi aktif dengan lingkungan yang menghasilkan perubahan-perubahan dalam pengetahuan, pemahaman, keterampilan, nilai, dan sikap, (d) Sdaffer, belajar merupakan perubahan tingkah laku yang relatif menetap, sebagai hasil pengalaman-pengalaman atau praktik. (heritl.blogspot.com/2007/12/belajardanmotivasinya)

Muhibbin Syah (2005:92) berpendapat bahwa "Belajar adalah tahapan perubahan seluruh tingkah laku individu yang relatif menetap sebagai hasil pengalaman dan interaksi dengan lingkungan yang melibatkan proses kognitif”.

Belajar adalah produk akhir dari sebuah proses belajar. Kemampuan menggunakan pengetahuan dan konsep belajar merupakan dasar dalam peningkatan prestasi belajar siswa. Mengingat keberadaan tersebut prestasi belajar tidaklah berdiri sendiri namun ia melekat pada banyak faktor lain.

Effendi (2007:29) menyatakan bahwa ketidaktenangan dan kerisauan atas hal-hal kecil seringkali mengganggu pelajar yang membuat meraka sulit untuk berkonsentrasi dengan baik, sehingga mempengaruhi prestasi belajarnya. Dengan berpedoman pada pernyataan tersebut dapat dijelaskan bahwa kondisi lingkungan berdampak langsung terhadap kejiwaan dan mental siswa yang pada akhirnya akan berpengaruh pula pada prestasi belajar. 
Hardwinoto dan Tony Setiabudhi (2007:36) menjelaskan bahwa supaya anak dapat belajar dengan baik, mereka memerlukan lingkungan yang menyenangkan agar mereka dapat mengingat dengan baik informasiinformasi yang diterima dan perlu adanya pengulangan agar tercipta ingatan jangka panjang. Prestasi belajar siswa terdiri dari berbagai kemampuan sesuai dengan tujuan belajar yang dialami siswa. Agar terbentuk dan terbangun prestasi belajar yang optimal, maka tujuan belajar seharusnya sesuai dengan bakat dan potensi siswa serta sesuai kondisi lingkungan belajar.

Prestasi belajar yang dicapai peserta didik, dipengaruhi secara langsung oleh proses belajar yang dilaluinya. Prestasi belajar tidak hanya terbatas pada kemampuan menghafal atau mengingat berbagai informasi verbal, namun prestasi belajar juga mencakup sikap, etika, perilaku, kemampuan bertindak dan berbagai kemampuan lain yang bermanfaat bagi siswa secara pribadi maupun kelompok masyarakat secara umum.

Menurut Purwanto (2007: 107), prestasi belajar di pengaruhi oleh hal-hal sebagai berikut:

1. Faktor dari Luar

a. Lingkungan, yang terdiri dari lingkungan alam dan lingkungan sosial.

b. Instrumental, yang terdiri dari kurikulum atau bahan ajar, guru atau pengajar, sarana dan fasilitas dan administrasi atau manajemen.

2. Faktor dari Dalam

a. Fisikologi, yang terdiri dari kondisi fisik dan kondisi panca indra.

b. Pisikologi, yang terdiri dari bakat, kecerdasan, motivasi, dan kemampuan kongnitif.

Berdasarkan uraian di atas dapat di simpulkan bahwa prestasi belajar adalah suatu perubahan tingkah laku secara keseluruhan secara sengaja, disadari dan perubahan tersebut relatif mantap serta membawa pengaruh dan manfaat yang positif bagi peserta didik dalam berinteraksi dengan lingkunganya, yang dapat diukur melalui faktor yang berasal dari dalam diri peserta didik (faktor internal) dan faktor dari luar diri peserta didik (faktor eksternal).

\section{Kreativitas Guru dalam Penggunaan Media}

Kata media merupakan bentuk jamak dari kata medium. Menurut Heinich yang dikutip Ibrahim (2001: 35) bahwa "Medium dapat didefinisikan sebagai 
perantara atau pengantar terjadinya komunikasi dari pengirim menuju penerima". Kreativitas adalah kemampuan seseorang untuk menemukan dan menciptakan hal-hal baru (Sukmadinata, 2009:107). Berdasarkan definisi tersebut, dapat dikatakan bahwa proses pembelajaran merupakan proses komunikasi. Proses pembelajaran mengandung lima komponen komunikasi, guru (komunikator), bahan pembelajaran, media pembelajaran, siswa (komunikan), dan tujuan pembelajaran.

Jadi, Media pembelajaran adalah segala sesuatu yang dapat digunakan untuk menyalurkan pesan (bahan pembelajaran), sehingga dapat merangsang perhatian, minat, pikiran, dan perasaan siswa dalam kegiatan belajar untuk mencapai tujuan belajar.

pembelajaran sebagai komponen komunikasi ditunjukkan pada Gambar 1 sebagai berikut:

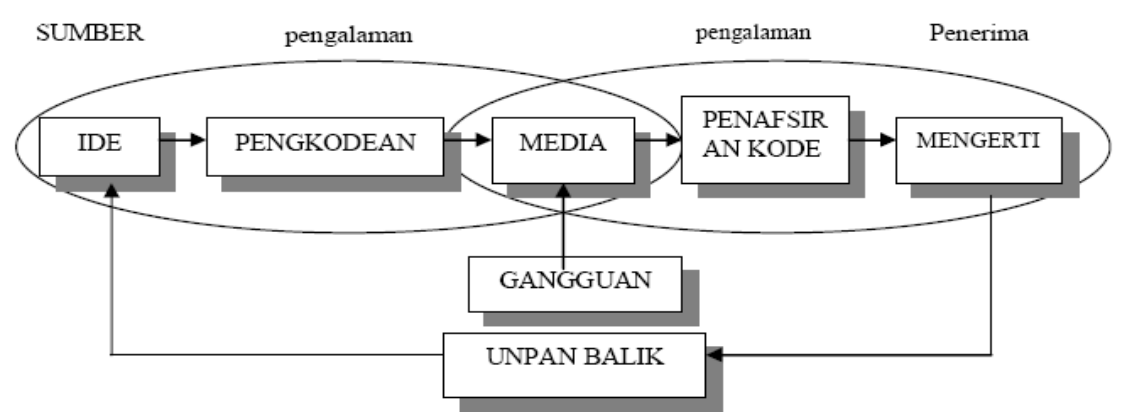

Gambar 1: Posisi Media dalam Pembelajaran

Fungsi media pembelajaran, dalam proses pembelajaran, media memiliki fungsi sebagai pembawa informasi dari sumber (guru) menuju penerima (siswa). Sedangkan metode adalah prosedur untuk membantu siswa dalam menerima dan mengolah informasi guna mencapai tujuan pembelajaran. Fungsi media dalam proses pembelajaran ditunjukkan pada Gambar 2

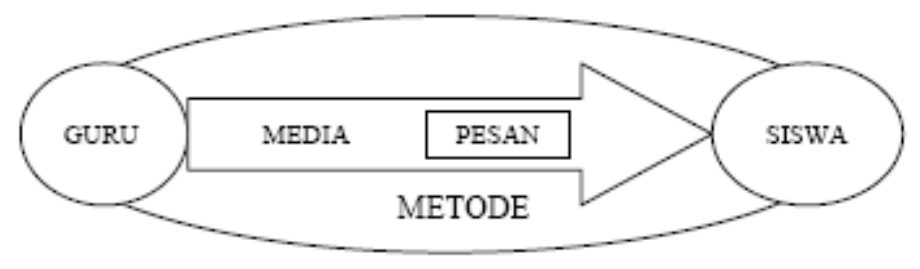

Gambar 2: Fungsi Media dalam Proses Pembelajaran 
Dalam kegiatan interaksi antara siswa dengan lingkungan, fungsi media dapat diketahui berdasarkan adanya kelebihan media dan hambatan yang mungkin timbul dalam proses pembelajaran. Tiga kelebihan kemampuan media (Gerlach \& Ely dalam Ibrahim, et.al., 2001) adalah sebagai berikut. Pertama, kemapuan fiksatif, artinya dapat menangkap, menyimpan, dan menampilkan kembali suatu obyek atau kejadian. Dengan kemampuan ini, obyek atau kejadian dapat digambar, dipotret, direkam, difilmkan, kemudian dapat disimpan dan pada saat diperlukan dapat ditunjukkan dan diamati kembali seperti kejadian aslinya. Kedua, kemampuan manipulatif, artinya media dapat menampilkan kembali obyek atau kejadian dengan berbagai macam perubahan (manipulasi) sesuai keperluan, misalnya diubah ukurannya, kecepatannya, warnanya, serta dapat pula diulang-ulang penyajiannya. Ketiga, kemampuan distributif, artinya media mampu menjangkau audien yang besar jumlahnya dalam satu kali penyajian secara serempak, misalnya siaran TV atau Radio.

Kreativitas guru adalah mereka yang secara teratur menempatkan diri mereka di sekitar ide-ide baru yang muncul dari berbagai sumber. Guru yang kreatif selalu ada hal yang baru demi kepercayaan peserta didiknya.

Kreativitas merupakan hal yang sangat penting dalam pembelajaran, dan guru dituntut untuk mendemonstrasikan dan menunjukan proses kreativitas tersebut. Kreativitas merupakan sesuatu yang bersifat universal dan merupakan ciri aspek dunia kehidupan di sekitar kita. Kreativitas ditandai oleh adanya kegiatan menciptakan sesuatu yang sebelumnya tidak ada dan tidak dilakukan oleh seseorang atau adanya kecenderungan untuk menciptakan sesuatu (E. Mulyasa, 2009: 51).

Kegiatan kreativitas guru dalam semua kegiatannya ditopang, dibimbing dan dibangkitkan oleh kesadaran. Guru menjadi creator dan motivator, yang berada di pusat proses pendidikan. Akibat fungsi tersebut, guru senatiasa untuk menemukan cara yang lebih baik dalam melayani siswa, sehingga siswa akan menilai bahwa guru memang kreatif dan tidak melakukan sesuatu secara rutin saja. Kreativitas guru menunjukkan apa yang dikerjakan sekarang lebih baik dari yang telah dikerjakan dan apa yang dikerjakan masa datang lebih baik dari sekarang. 
Peran kreativitas guru dapat dilihat pada proses pembelajaran di tengah kemajuan ilmu pengetahuan dan teknologi yang begitu pesat, dimana guru berperan sebagai:

1. Sumber belajar, peran guru sebagai sumber belajar berkaitan erat dengan penguasaan materi pelajaran, guru dapat menjawab setiap pertanyaan siswa dengan penuh keyakinan, guru dapat melakukan berbagai hal seperti:
a. Guru memiliki bahan referensi lebih banyak dibandingkan siswa
b. Guru dapat menunjukakan sumber belajar yang dapat dipelajari siswa
c. Guru dapat melakukan pemetaan materi pelajaran

2. Fasilitator, guru berperan dalam memberikan pelayanan untuk memudahkan siswa dalam kegiatan proses pembelajaran, dengan memanfaatkan berbagai media dan sumber pembelajaran diantaranya:

a. Guru memahami berbagai jenis media dan sumber belajar beserta fungsi masing-masing media tersebut karena setiap media mempunyai karakteristik yang berbeda.

b. Guru mempunyai keterampilan dalam merancang suatu media, dengan merancang media yang dianggap cocok akan memudahkan proses pembelajaran.

c. Guru mampu mengorganisasikan berbagai jenis media serta dapat memanfaatkan berbagai sumber belajar. Berbagai perkembangan teknologi informasi memungkinkan guru bisa menggunakan berbagai pilihan media yang cocok.

d. Guru mampu berinteraksi dan berkomunikasi dengan siswa, sehingga siswa dapat menangkap pesan dengan baik dan dapat memotivasi belajar siswa.

3. Guru sebagai pengelola, guru mampu menciptakan iklim belajar yang memungkinkan siswa dapat belajar secara nyaman, melalui pengelolan kelas yang baik dan kondusif.

4. Guru sebagai demonstrator, mampu menunjukkan kepada siswa segala sesuatu yang dapat membuat siswa lebih mengerti dan memahami setiap pesan yang disampaikan.

5. Guru sebagai pembimbing, siswa merupakan individu yang unik, tidak ada individu yang sama secara bakat, minat dan kemampuan. Perbedaan ini, guru 
harus mampu membimbing agar siswa dapat menemukan potensi yang dimilikinya.

6. Guru sebagai motivator, guru dituntut mampu dan kreatif membangkitkan semangat siswa.

Menurut Rhode dalam Reni Akbar-Hawadi (2001:3) kreativitas dapat didefinisikan ke dalam empat jenis dimensi sebagai "Four P's of Creativity, yaitu dimensi Person, Process, Press, Product”.

Sedangkan Rusman (2008:86-87), menjelaskan ada beberapa kriteria pemilihan media pembelajaran, yaitu:

1. Ketepatannya dengan tujuan/kompetensi pembelajaran; artinya media pembelajaran dipilih atas dasar tujuan-tujuan instruksional atau kompetensi yang telah ditetapkan.

2. Dukungan terhadap isi materi pelajaran; artinya bahan pelajaran yang sifatnya fakta, prinsip, konsep dan generalisasi sangat memerlukan bantuan media agar lebih mudah dipahami siswa.

3. Kemudahan mendapat media; artinya media yang diperlukan mudah diperoleh, setidak-tidaknya mudah dibuat oleh guru pada saat menggajar.

4. Keterampilan guru menggunakannya; artinya secanggih apapun sebuah media apabila tidak tahu cara menggunakannya maka media tersebut tidak memiliki apa-apa.

5. Tersedia alokasi waktu untuk menggunakannya; sehingga media tersebut dapat bermanfaat bagi siswa selama proses pembelajaran berlangsung.

6. Memilih media pembelajaran harus sesuai dengan taraf berfikir dan perkembangan siswa, sehingga makna yang terkandung di dalamnya dapat dipahami dan mudah dimengerti oleh para siswa.

Strategi-strategi yang dapat membantu pengembangan kreativitas muridmurid secara efektif menurut Anna Craft (2004:177) mencakup:

1. Menggunakan humor (menggunakan banyak teknik yang berbeda dalam satau mata pelajaran untuk membuat kelasnya tertawa).

2. Membujuk individu-individu secara akrab

3. Menyebut individu-individu dengan nama 
4. Secara umum harapan guru yang tinggi mencakup dorongan positif untuk memperoleh jawaban benar (untuk sebagian besar murid-bukan untuk orangorang yang berusaha keras); dan

5. Membuat langkah cepat.

Dalam ruang kelas seperti itu terdapat sebutan suasana gembira, menyenangkan dan inklusi. Tiap anak diakui sebagai seorang anggota dari kelas secara keseluruhan, dan juga sebagai seorang individu dengan hak mereka sendiri.

Strategi untuk memegang kontrol yang teguh dalam sebuah pola guru sebagai inti, namun murid sebagai fokus, termasuk memiliki aturan yang berlaku jelas pada manajemen ruang kelas (secara umum murid semua duduk, sedangkan guru berdiri; pengaturan ruang kelas berarti bahwa murid dan guru saling berhadaphadapan, dan dengan mudah akan terjadi kontak mata).

Menurut Fryer seperti dikutip Anna Craft (2004:179) menemukan "kewajaran pada korelasi yang erat antara orientasi pada kreativitas dengan orientasi personal, atau penilaian atas hubungan." Ia mencatat bahwa kabanyakan guru kreatif, secara aktif mengganti metode dan mengajak berpartisipai kepada tiap murid dalam pembelajaran dan berfikir untuk diri mereka sendiri. Kreativitas anak yang menjadi berkembang disebuah lingkungan yang memiliki struktur dan kebebasan; dapat diprediksi secara fleksibel, di mana para murid diakui sebagai pemikir yang memiliki kemampuan, di mana harapan-harapannya tinggi, dan di mana hubungan antara orang dewasa dan anak-anak adalah otentik.

Berdasarkan teori yang diungkapkan di atas dapat disimpulkan kreativitas guru adalah suatu aktivitas mencipta/daya cipta tertentu yang dilakukan oleh guru yang mendukung proses belajar mengajar yang dilandasi atau didasari oleh product, person, process, press yang didukung oleh pengetahuan.

\section{Minat}

Minat menurut Mursad yang dikutip Syaiful Bahri (2000:60), menyatakan, minat adalah "kesadaran seseorang bahwa suatu obyek seseorang atau soal, atau situasi mengandung sangkut paut dengan dirinya”.

William James mengatakan bahwa minat siswa merupakan faktor utama yang menentukan derajat keaktifan belajar siswa (Usman, 2003:27). 
Menurut Usman (2003:27) kondisi belajar mengajar yang efektif adalah adanya minat dan perhatian siswa dalam belajar. Minat merupakan suatu sifat yang relatif menetap pada diri seseorang.

Minat ini besar pengaruhnya terhadap belajar karena minat siswa merupakan faktor utama yang menentukan derajat keaktifan siswa, bila bahan pelajaran yang dipelajari tidak sesuai dengan minat siswa, siswa tidak akan belajar dengan sebaik-baiknya sebab tidak ada daya tarik baginya. Oleh karena itu, untuk mengatasi siswa yang kurang berminat dalam belajar, guru hendaknya berusaha bagaimana menciptakan kondisi tertentu agar siswa itu selalu butuh dan ingin terus belajar, dalam artian menciptakan siswa yang mempunyai minat belajar yang besar, mungkin dengan cara menjelaskan hal-hal yang menarik, salah satunya adalah mengembangkan variasi model dalam gaya mengajar. Dengan variasi ini siswa bisa merasa senang dan memperoleh kepuasan terhadap belajar.

Winkel (2004:105) mengatakan bahwa "Minat adalah kecenderungan subyek menetap, untuk merasa tertarik pada bidang studi atau pokok bahasan tertentu dan merasa senang mempelajari materi itu. yaitu: Kesadaran, kemauan, perhatian dan perasaan senang.

1. Kesadaran pada taraf ini adalah kesadaran terhadap sesuatu yang ada dalam satu situasi, baik berupa fenomena atau objek.

2. Kemauan untuk menerima ini menggambarkan tingkah laku individu yang mau menerima stimulus; atau dengan kata lain, individu mempunyai kemauan untuk menerima rangsang yang ditimbulkan oleh fenomena (kemauan sukarela individu untuk melakukan aktivitas).

3. Pengontrolan atau perhatian yang terpilih merupakan perhatian terhadap rangsang atau fenomena objek yang telah dipilih individu.

4. Keterlibatan perasaan seseorang terhadap suatu objek atau perasaan seseorang yang tidak dapat dipisahkan dengan objek atau aktivitas, karena adanya kaitan antara individu dengan aktivitas yang disukai tersebut.

Jadi dapat disimpulkan minat merupakan kecenderungan jiwa yang sifatnya aktif yang senantiasa berhubungan dengan kesadaran, perhatian, kemauan, dan kesenangan atau perasaan senang terhadap suatu obyek yang ada sangkut paut dengan dirinya. 


\section{METODE}

Metode penelitian yang digunakan adalah metode survei dengan pendekatan regresi linear berganda. Pengaruh antara variabel bebas dan tergantung. Penelitian ini dapat digambarkan dalam bentuk model analisis regresi linear berganda, seperti pada gambar berikut:

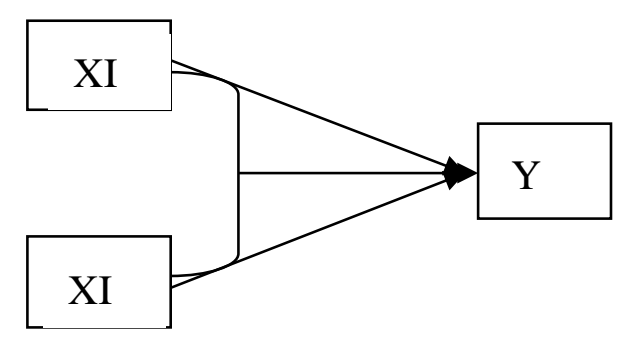

Gambar 3. Model Regresi Linear Berganda

Keterangan:

X1: Persepsi Kreativitas Guru dalam Penggunaan Media Belajar

X2: Minat Belajar

Y : Prestasi Belajar

Populasi dalam penelitian ini adalah seluruh peserta didik Sekolah Menengah Kejuruan (SMK) Swasta di Jakarta Selatan.

Jumlah Sekolah Menengah Kejuruan Swasta Jakarta Selatan (104). Sampel penelitian ini sebanyak 160 peserta didik sekolah menengah kejuruan yang tersebar di Jakarta Selatan yang ditentukan dengan menggunakan teknik Accidental sampling atau convenience sampling, dalam penelitian bisa saja terjadi diperolehnya sampel yang tidak direncanakan terlebih dahulu, melainkan secara kebetulan, yaitu unit atau subjek tersedia bagi peneliti saat pengumpulan data dilakukan. Proses diperolehnya sampel semacam ini disebut sebagai penarikan sampel secara kebetulan. (Sugiarto, 2001)

Berikut ini adalah ringkasan hasil ujicoba instrument penelitian:

Tabel. 1 Ringkasan Hasil Uji Coba Instrumen

\begin{tabular}{|c|c|c|c|c|c|c|}
\hline No & Variabel & Jenis Instrumen & $\begin{array}{c}\text { Jumlah Sebelum } \\
\text { Uji }\end{array}$ & $\begin{array}{c}\text { Jumlah Setelah } \\
\text { Uji }\end{array}$ & Reliabilitas & Validitas \\
\hline 1 & $\begin{array}{c}\text { Kreativitas guru } \\
\text { dalam penggunaan } \\
\text { media belajar }\end{array}$ & Angket & 15 & 15 & 0,915 & Rata-rata 0,677 \\
\hline 2 & Minat Belajar & Angket & 15 & 15 & 0,864 & Rata-rata 0,606 \\
\hline 3 & Prestasi Belajar & Angket & 15 & 15 & 0,796 & Rata-rata 0,536 \\
\hline
\end{tabular}


Tabel. 2 Ringkasan Hasil Uji Persyaratan Data

\begin{tabular}{ccccc}
\hline No. & Variabel & Uji Normalitas & Uji Linearitas & Simpulan \\
\hline 1 & Kreativitas guru dalam & 0,053 & 0,001 & Normal dan Linear \\
& penggunaan media belajar & & & \\
2 & Minat Belajar & 0,200 & 0,000 & Normal dan Linear \\
3 & Prestasi Belajar & 0,200 & & Normal dan Linear \\
\hline
\end{tabular}

HASIL DAN PEMBAHSAN

Tabel. 3 Ringkasan Analisis Regresi Linear Ganda

\begin{tabular}{cccccccc}
\hline & R & KD & Sig. f & f hitung & Sig. t & thitung & $\begin{array}{c}\text { Persamaan } \\
\text { Regresi }\end{array}$ \\
\hline X1 & & & & & 0,049 & 1,984 & Y=33,160+ \\
X2 & 0,442 & $19,5 \%$ & 0,000 & 19,044 & & 4,918 & $0,125 \mathrm{X} 1+$ \\
& & & & & 0,000 & & $0,280 \mathrm{X} 2$ \\
\hline
\end{tabular}

\section{PEMBAHASAN}

Hasil analisis menunjukkan adanya: (1) pengaruh positif dan signifikan variabel kreativitas guru dalam penggunaan media belajar (X1) dan minat belajar (X2) secara simultan terhadap prestasi belajar peserta didik (Y) dengan nilai $\mathrm{f}$ hitung 19,044, (2) pengaruh positif dan signifikan variabel kreativitas guru dalam penggunaan media belajar (X1) secara partial terhadap prestasi belajar peserta didik (Y) dengan niali t hitung 1,984, dan (3) pengaruh positif dan signifikan variabel minat belajar (X2) secara partial terhadap prestasi belajar peserta didik dengan nilai t hitung 4,918 .

Hasil penelitian ini mendukung penelitian sebelumnya yang dilakukan oleh Chandra Putri Tirtiana (2013) Untuk mengembangkan kreativitas siswa dalam pembelajaran, guru perlu menciptakan situasi belajar mengajar yang banyak memberi kesempatan kepada siswa untuk memecahkan masalah, melakukan beberapa percobaan, mengembangkan gagasan atau konsep-konsep siswa sendiri. Sehingga tingkat kepercayaan diri siswa menjadi meningkat. Adanya pengaruh penggunaan media pembelajaran power point terhadap hasil belajar. Media pembelajaran yang sesuai dengan ketepatan penggunaan, berupa kesesuaian dengan tujuan pembelajaran, tingkat pemahaman siswa, waktu yang lebih singkat membuat kegiatan belajar mengajar disekolah berjalan dengan lancar. Pembuatan media pembelajaran yang sesuai dengan taraf berfikir siswa 
membuat siswa dapat memahami materi secara cepat, dan dapat diulang ketika mereka berada di rumah, sehingga mereka termotivasi untuk belajar.

Adanya pengaruh langsung dan tidak langsung penggunaan media pembelajaran power point terhadap hasil belajar. Dengan menggunakan media pembelajaran, siswa dapat memahami penjelasan guru tentang suatu materi dengan jelas dan dapat mengetahui contoh materi belajar secara konkret. Sehingga siswa teromotivasi untuk belajar dan mendapatkan hasil belajar yang maksimal. Siswa dapat termotivasi untuk belajar setelah mereka tertarik dengan media yang digunakan oleh guru untuk menyampaikan materi. Motivasi tersebut dapat tercermin dari siswa yang bersemangat untuk belajar, menyelesaikan tugastugasnya, dan berusaha untuk menjadi orang yang sukses. Untuk memenuhi hal tersebut guru seharusnya memanfaatkan media pembelajaran untuk meningkatkan motivasi belajar siswa sehingga hasil belajarnya menjadi baik. Misalnya dengan menampilkan contoh bukti transaksi pada slide atau film tentang bagaimana transaksi dilakukan, sehingga siswa memiliki gambaran bagaimana transaksi dilakukan secara nyata.

Setelah guru menggunakan media, aktivitas belajar siswa akan menjadi lebih menyenangkan dan menarik. Setelah siswa tertarik untuk belajar, mereka akan menyimak. pelajaran dengan baik, tidak mengantuk, bercerita dengan teman, atau melakukan aktivitas lain yang tidak mendukung proses belajar mengajar. Penggunaan media pembelajaran juga mempermudah guru untuk membantu siswa memahami materi, ketika siswa dapat memahami materi maka hasil belajar akan menjadi maksimal. Hal ini sesuai teori yang dikemukakan oleh Sadiman (2011: 17), yang menyatakan bahwa media pembelajaran mempunyai fungsi memperjelas penyajian pesan agar tidak terlalu bersifat verbalisme, mengatasi keterbatasan waktu, ruang dan daya indra, penggunaan media dapat mengatasi sifat pasif pada siswa.

Penelitian ini juga sejalan dengan penelitian yang dialakukan Keke T. Aritonang (2008) Hal ini menunjukkan bahwa hasil belajar tidak saja pada faktor minat dan motivasi tetapi juga pada faktor lainnya seperti cara mengajar guru, karakter guru, suasana kelas tenang dan nyaman, dan fasilitas belajar yang digunakan. Faktor yang paling utama yang menentukan apakah siswa akan berminat dan termotivasi untuk belajar adalah faktor dari guru sendiri. Karena 
guru sebagai fasilitator harus mampu memilih dan mengolah metode, strategi dan motif mengajar yang dapat meningkatkan minat dan motivasi belajar para siswa dan guru terlibat langsung dalam proses belajar-mengajar.

Langkah-langkah dan Faktor-faktor untuk Membangkitkan Minat dan Motivasi Belajar Siswa Melalui Peran Guru. Proses belajar-mengajar dan hasil belajar siswa sebagian besar ditentukan oleh peranan dan kompetensi guru. Guru yang kompeten akan lebih mampu menciptakan lingkungan belajar yang efektif dan akan lebih mampu mengelola kelasnya sehingga hasil belajar siswa akan lebih mampu mengelola kelasnya sehingga hasil belajar siswa berada pada tingkat optimal. Peranan dan kompetensi guru dalam proses belajar-mengajar menurut Usman (2003 : 9) diklasifikasikan sebagai berikut:

1. Guru sebagai demonstrator

Yang harus dimiliki guru sebagai demonstrator adalah: (a) menguasai bahan atau materi pelajaran yang akan diajarkan, (b) harus belajar terus-menerus sehingga kaya dengan berbagai ilmu pengetahuan, dan (c) mampu dan terampil dalam merumuskan standar kompetensi, memahami kurikulum, memberikan informasi kepada kelas, memotivasi siswa untuk belajar, dan menguasai serta mampu melaksanakan keterampilan-keterampilan mengajar.

2. Guru sebagai pengelola kelas

Yang harus dimiliki guru sebagai pengelola kelas, yaitu: (a) dapat memelihara lingkungan fisik kelasnya, (b) membimbing pengalaman-pengalaman siswa sehari-hari ke arah self directed behavior, dan (c) menyediakan kesempatan bagi siswa untuk mengurangi ketergantungannya pada guru, (d) mampu memimpin kegiatan belajar yang efektif serta efisien dengan hasil optimal, dan (e) mampu mempergunakan pengetahuan teori belajar-mengajar dan teori perkembangan.

3. Guru sebagai mediator dan fasilitator

Yang harus dimiliki guru sebagai mediator dan fasilitator adalah: (a) memiliki pengetahuan dan pemahaman tentang media pendidikan, (b) memiliki keterampilan memilih dan menggunakan serta mengusahakan media dengan baik, (c) terampil mempergunakan pengetahuan berinteraksi dan berkomunikasi, dan (d) mampu mengusahakan sumber belajar yang berguna serta dapat menunjang pencapaian tujuan dan proses belajar mengajar. 
4. Guru sebagai evaluator

Yang harus dimiliki guru sebagai evaluator, adalah: (a) mampu dan terampil melaksanakan penilaian, (b) terus-menerus mengikuti hasil belajar yang telah dicapai siswa dari waktu ke waktu, dan (c) dapat mengklasifikasikan kelompok siswa yang pandai, sedang, kurang, atau cukup baik di kelasnya.

\section{SIMPULAN}

1. Terdapat pengaruh kreativitas guru dalam penggunaan media belajar dan minat belajar secara simultan terhadap prestasi belajar peserta didik. Hal ini menandakan bahwa semakin kreatif guru dalam memanfaatkan media belajar akan menumbuhkan minta belajar peserta didik yang pada akhirnya dapat meningkatkan prestasi belajar peserta didik.

2. Terdapat pengaruh kreativitas guru dalam pengunaan media belajar secara partial terhadap prestasi belajar peserta didik. Hal ini menandakan bahwa semakin kreatif dan bervariatif guru dalam menggunakan media belajar, semakin semangat peserta didik mengikuti pembelajaran, dan pada akhirnya dapat meningkatkan prestasi belajar peserta didik .

3. Terdapat pengaruh minat belajar secara partial terhadap prestasi belajar peserta didik. Hal ini menandakan bahwa semakin baik dan semakin tinggi minat yang dimiliki peserta didik dalam pembelajaran, akan meningkatkan prestasi belajar peserta didik.

\section{KETERBATASAN PENELITIAN}

Hasil penelitian yang sempurna tidak mudah didapat, begitu juga dengan penelitian ini yang memiliki keterbatasan-keterbatasan dalam pelaksanaan penelitian sebagaimana berikut ini:

1. Penelitian dibatasi hanya pada Peserta Didik Sekolah Menengah Kejuruan di Jakarta Selatan.

2. Pengambilan sampel dalam penelitian ini menggunakan teknik Accidental sampling atau convenience sampling, dalam penelitian bisa saja terjadi diperolehnya sampel yang tidak direncanakan terlebih dahulu, melainkan secara kebetulan, yaitu unit atau subjek tersedia bagi peneliti saat pengumpulan data dilakukan, dengan asumsi bahwa seluruh peserta didik Sekolah Menengah Kejuruan di Jakarta Selatan kondisinya relatif homogen, 
tanpa memperhitungkan status sekolah, tingkat kelas peserta didik, jenis kelamin peserta didik dan sebagainya. Untuk mengumpulkan data dalam penelitian ini menggunakan kuesioner, dengan bentuk angket langsung dan tertutup.

3. Hanya 2 variabel yang diteliti dalam rangka meningkatkan prestasi belajar peserta didik, yaitu kreativitas guru dalam penggunaan media belajar dan minat belajar. Pada kenyataannya, prestasi belajar peserta didik tidak sepenuhnya hanya dipengaruhi oleh kedua variabel tersebut. Oleh karena itu, diharapkan bagi para peneliti selanjutnya dapat mengkaji prestasi belajar tidak hanya ditinjau dari kedua variabel tersebut.

4. Hasil yang diperoleh dalam penelitian ini boleh jadi merupakan informasi pendahuluan yang masih perlu dikaji ulang melalui penelitian lebih lanjut. Namun, hasil-hasil yang diperoleh dalam penelitian ini tetap dapat dipandang sebagai suatu kenyataan empirik yang dapat dipertanggung jawabkan, karena penelitian dilakukan berdasarkan pedoman metodologi.

\section{UCAPAN TERIMA KASIH}

Dengan ini penulis mengucapkan rasa syukur kepada Allah SWT yang telah memberikan rahmat dan hidayah-Nya, serta penulis mengucapkan terima kasih kepada jurnal RDJE Universitas Indraprasta PGRI, ucapan terima kasih kepada Kepala Sekolah, Guru, dan Peserta Didik Sekolah Menengah Kejuruan di wilayah Jakarta Selatan, ucapan terima kasih kepada semua pihak yang tidak dapat disebutkan satu persatu yang telah memberikan bantuan dan dukungan kepada penulis.

\section{DAFTAR PUSTAKA}

\section{Buku:}

Anna Craft. 2004. me-Refresh Imajinasi \& Kreativitas Anak-Anak. Depok: Cerdas Pustaka.

Effendy, Onong Uchjana. 2007. Ilmu Komunikasi (teori dan Praktek). Bandung: PT. Remaja Rosdakarya.

Hamalik, Oemar. 2005. Strategi Belajar Mengajar. Bandung: Mandar Maju.

Hardywinoto \& Setiabudhi, T. 2007. Panduan Gerontologi. Jakarta: Pustaka Utama. 
Research and Development Journal Of Education

Vol. 5 No. 1 Oktober 2018

ISSN 2406-9744

Ibrahim, H., Sihkabuden, Suprijanta, \& Kustiawan, U. 2001. Media pembelajaran: Bahan sajian program pendidikan akta mengajar. FIP. UM.

Muhibbin Syah. 2005. Psikologi Pendidikan. Bandung: Remaja Rosdakarya.

Purwanto. 2007. Evaluasi Hasil Belajar.Jakarta: Pustaka Pelajar

Reni Akbar-Hawadi. 2001. Buku Dua dari Tiga Kreativitas. Jakarta: Grasindo.

Sardiman. 2011. Interaksi dan Motivasi Belajar Mengajar. Jakarta: PT Raja Grafindo Persada

Sudjana, Nana. 2005. Proses Belajar Mengajar. Bandung: Sinar Baru Algensindo

Sukmadinata, Nana Syaodih, 2009. Landasan Psikologi Proses Pendidikan. Bandung: Remaja Rosda Karya.

Syaiful Bahri Djamarah. 2000. Prestasi Belajar Dan Kompetensi Guru. Surabaya: Usaha Nasional.

Usman, Uzer. 2003. Menjadi guru profesional. Bandung: Penerbit PT Remaja Rosdakarya

Winkel. 2004. Psikologi Pendidikan. Jakarta: PT. Grasindo

Jurnal:

Chandra Putri Tirtiana. 2013. Pengaruh Kreativitas Belajar, Pengunaan Media Pembelajaran Power Point, dan Lingkungan Keluarga Terhadap Hasil Belajar Mata Pelajaran Akuntansi Pada Siswa Kelas X Akt SMK Negeri 2 Blora Tahun Ajaran 2012/2013 (Motivasi Belajar Sebagai Variabel Intervening). Econpmic Educational Analysis Journal 2(2) 2013.

Keke T. Aritonang. 2008. Minat dan Motivasi dalam Meningkatkan Hasil Belajar Siswa. Jurnal Pendidikan Penabur No. 10 Tahun ke-7 Juni 2008.

\section{Peraturan Perundangan:}

.Undang-undang RI No. 14 Tahun 2005 Tentang Guru dan Dosen

\section{Inter Net:}

heritl.blogspot.com/2007/12/belajar-danmotivasinya

Rusman. 2008. Pembelajaran Kooperatif Tipe Jigsaw. http://style-lecture. blogspot.com/2012/09/pembelajaran-kooperatif-model-jigsaw.html 